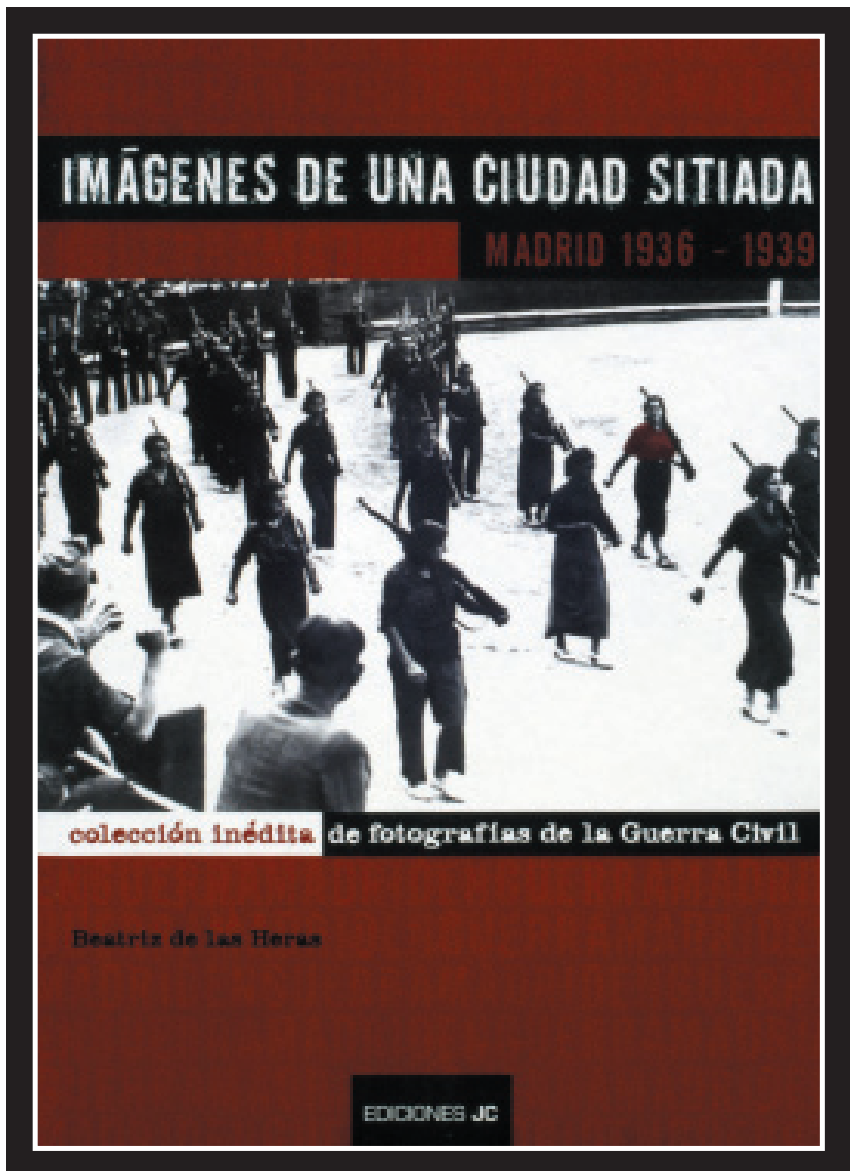

Imágenes de una ciudad sitiada - Madrid 1936-1939:

Colección inédita de fotografías de la Guerra Civil, de Beatriz de las Heras. Madrid: Ediciones JC, 2009, 207 p. 


\title{
O mosaico fotográfico de ¡No passarán!
}

\author{
FabianaA.Alves*
}

O primeiro acontecimento do século XX que contou com uma cobertura diária de fotógrafos, vindos de várias partes do mundo, foi a Guerra Civil Espanhola. Antes, a Primeira Grande Guerra (1914-1918) também havia sido coberta por jornalistas de vários países, mas não com produção feita dia-a-dia. Hoje as imagens produzidas por estes profissionais possibilitam a recuperação de testemunhos visuais do conflito. Afinal, a fotografia é um suporte da memória fundamental para se aproximar do passado devido à capacidade de cortar o espaço e capturar o tempo daqueles que retratam.

Madri se tornou um dos principais cenários daquele momento e, até hoje, muitas imagens inéditas são localizadas por pesquisadores. É neste sentido que Beatriz de las Heras constrói sua obra. A autora apresenta uma coleção de fotografias conservadas no Arquivo Geral da Nação Argentina, em Buenos Aires, adquiridas durante a guerra pelo jornal também argentino - Noticias Gráficas. Em um total de 83 imagens, a realidade de Madri no período foi retratada, focando, em especial, os cidadãos e os soldados entre julho de 1936 e abril de 1939. Heras divide as fotografias em dois momentos: o front e a retaguarda.

A obra, por sua vez, é organizada em cinco partes. Na primeira, a autora, que é professora da área de História Contemporânea do Departamento de Humanidades da Universidade Carlos III de Madri, aborda a fotografia como fonte para o estudo da história. $\mathrm{O}$ capítulo seguinte é destinado a discussões sobre a fotografia de guerra e, sobretudo, ao caso de Madri entre 1936 e 1939. A terceira parte conta um pouco da história do jornal Noticias Gráficas e explica como o acervo fotográfico foi adquirido pelo Arquivo Nacional. Neste momento, Heras ainda descreve

\footnotetext{
* Jornalista e historiadora. Mestranda em Comunicação da Universidade Estadual de Londrina (UEL). Bolsista da Capes.
} 
todos os 83 registros imagéticos explorados em seu trabalho. O próximo capítulo trata da análise deste material. Já o último traz todas as fotografias elencadas e as informações de cada uma existente no arquivo, separadas em "Retaguarda", com 52 imagens, e"Vanguarda", com 31.

Heras aponta que a fotografia é fonte histórica não só porque se apresenta como uma extensão do olho (a memória natural pensa em imagens), mas também por ser uma extensão da memória (a fotografia como uma de suas funções). Assim, "funciona em nossas mentes como uma espécie de passado preservado". ${ }^{1}$ (HERAS, 2009, p.20).

Para a autora, é necessário que a história se relacione com disciplinas como a comunicação visual, desde a semiótica, filosofia da imagem, até a sociologia e psicologia da percepção. Contudo, ressalta que o historiador deve criar seu próprio método para afrontar a fotografia como fonte. $\mathrm{O}$ estudo deve considerar a imagem como um documento histórico portador de múltiplos significados, levando em conta sua natureza de fragmento e registro documental e, ainda, o momento histórico do ato de tomada. Também se deve realizar uma análise técnica e iconográfica e dar conta de cada um dos elementos que interferem no processo comunicacional: do autor (fotógrafo) ao leitor (espectador), do contexto e filtros que rodeiam a captura e a recepção. Para tanto, acredita que a análise imagética deve ser feita como na arqueologia, tratando a fotografia como um "achado arqueológico". ${ }^{2}$ Conforme Heras (2009, p.21):

é uma peça que se localizada, resgata-se, limpa-se de possíveis restos que impedem de apreciar o documento, determinam-se seus elementos constitutivos e se detectam as informações que contém para, finalmente, encadeá-lo com outras tesselas de informações que nos permitem reconstruir esse passado como um mosaico. ${ }^{3}$

\footnotetext{
${ }^{1}$ Tradução livre do original: "funciona en nuestras mentes como una especie de pasado preservado".

2 Tradução livre do original: "hallazgo arqueológico".

${ }^{3}$ Tradução livre do original: "es una pieza que se localiza, se rescata, se limpia de los posibles restos que impiden apreciar el documento, se determinan sus elementos constitutivos y se detectan las informaciones que contiene para, finalmente, engarzarlo con otras teselas de información que nos permitan reconstruir ese pasado a modo de mosaico".
} 
Heras também alerta que a aparente objetividade da fotografia mascara. Então, é preciso dar atenção às possíveis intencionalidades, incorporações, manipulações e persuasões presentes na imagem. Só assim o historiador conseguirá dotá-la da capacidade narrativa para obter discursos visuais por meio da relação estabelecida entre vários instantes. Segundo Heras (2009, p.22), "assim se superará o instante, o que apresenta umúnico fragmento de memória, para recriar um processo narrativo visual que o permita a recuperação da memória coletiva". ${ }^{4}$

No caso da Guerra Civil Espanhola, existem muitas imagens que contam a história do momento, pois inúmeros fotógrafos fizeram a cobertura do evento, como Robert Capa, Gerda Taro, David Seymour, Jean Moral e, entre os espanhóis, Manuel Albero e Francisco Segovia, Marín, José María Casariego, Alfonso, entre outros. Muitas agências internacionais enviaram seus melhores correspondentes, realizando, assim, o maior desdobramento jornalístico da época. O interesse desses profissionais se deve, segundo a autora, a três razões: o aparecimento do fotojornalismo moderno no anos 20, a predileção de revistas e jornais por material gráfico para ilustrar suas notícias - privilegiando a imagem em relação ao texto e ao desenvolvimento da tecnologia aplicada à fotografia - como a criação de câmeras como a Ermanox e a Rolleiflex e os filmes fotográficos mais sensíveis. Desta forma, os fotógrafos podiam passar despercebidos e substituir as tomadas posadas e estáticas pela naturalidade da ação.

Heras lembra os perigos enfrentados pelos fotógrafos, justamente porque passaram a acompanhar a dinâmica militar, e as dificuldades de muitos para conseguir material para trabalhar. Este último atingiu, sobretudo, os espanhóis devido às restrições impostas pelo conflito. Os profissionais estrangeiros recebiam ou iam buscar o que precisavam em seus países de origem. Alguns espanhóis chegaram a utilizar filmes cinematográficos para fotografar e também recorreram às suas câmeras antigas, com as trabalhosas chapas.

\footnotetext{
${ }^{4}$ Tradução livre do original: “Así superará el instante, el que aporta un único fragmento de memoria, para recrear un proceso narrativo visual que le permita la recuperación de la memoria colectiva."
} 
A autora enfatiza a importância dada pelas autoridades de Madri à propaganda. Afinal, era preciso convencer as potências democráticas mundiais das atrocidades cometidas pelos apoiadores do general Francisco Franco e combater o fascismo. Além disso, necessitava-se manter a moral dos madrilenos em alta para que continuassem a resistir aos avanços da oposição. Madri, durante o confronto, tornou-se o centro de interesse dos dois lados envolvidos. Era duplamente atrativa: sua localização geoestratégica facilitava o acesso a todas as regiões (mérito militar) e era a capital de um estado fortemente centralizado (mérito simbólico). Frente a este panorama, somente o ânimo de um povo, que decidiu se armar para se defender, foi capaz de deter o avanço inimigo e transformar Madri na capital do "Não passarão!". 5

O governo legal e democrático investiu pesado na exploração propagandística. Tanto que recebeu críticas por ter se dedicado mais a fazer campanhas mostrando a maldade dos franquistas e a bondade dos antifascistas do que às estratégias militares necessárias para a resolução do conflito. O suporte mais empregado para estes trabalhos foi o visual, devido a sua capacidade de persuasão que o fazia uma arma muito eficiente para "condicionar a um público desejoso de informação e facilmente manipulável devido ao progresso da guerra, de tal modo que os cartazes e as fotografias tomadas no front e na retaguarda invadiam muros, periódicos e revistas". ${ }^{6}$ (HERAS, 2009, p.26). A fotografia, neste contexto, era entendida não só como um elemento propagandístico, mas também como um suporte que, por conter informações privilegiadas - era o meio mais cercado de realidade -, não poderia cair nas mãos dos inimigos.

As imagens analisadas por Heras pertenciam ao acervo do periódico vespertino argentino, Noticias Gráficas, fundado em 1931. Ele foi um dos primeiros jornais do país a ter um departamento de fotografia estável e sua tiragem chegou a atingir 300 mil exemplares nas três edições diárias.

\footnotetext{
5 Tradução livre do original: “¡No passarán!”

${ }^{6}$ Tradução livre do original: "condicionar a un público deseoso de información y fácilmente manipulable debido al avance de la contienda, de tal modo que los carteles y las fotografías tomadas en el frente y en la retaguardia invadían muros, periódicos y revistas".
} 
Com uma grave crise que se iniciou na década de 60 , o Noticias, junto com outros veículos, desapareceu em 1963. Em outubro de 1971, a coleção fotográfica do diário foi adquirida pelo Arquivo Geral da Nação Argentina, que justificou a compra por ser um acervo de valioso testemunho do trabalho nacional em um amplo período.

As fotografias, em papel, estão conservadas, em condições inapropriadas, em uma caixa no porão do edifício. As que não possuem negativos, sendo originais únicos, foram incorporadas ao arquivo da instituição e estão guardadas em várias caixas e bolsas repartidas em diferentes prateleiras. $\mathrm{O}$ material está conservado em 35 envelopes dedicados a diferentes aspectos da história e da arte espanhola. Heras explorou as 83 imagens contidas nos envelopes 12 a 21, tomadas em Madri entre julho de 1936 e abril de 1939. Não existe registro dos autores das imagens e nem outra informação de interesse dos pesquisadores, salvo alguns escritos nos versos das fotografias. A autora descreve e apresenta cada uma das imagens, respeitando o número do envelope no qual estão conservadas, o número do documento original e o texto que aparece nos versos (inclusive o idioma original).

Das 83 fotografias, uma é fotomontagem que traz uma imagem de uma mulher que corre assustada com o filho no colo e a frase: "O que você faz para evitar isto? Ajude Madri." "Outros dois instantâneos foram tomados durante a entrada das tropas de Franco na capital. Um mostra a evocação de alguns civis a um caminhão que carregava um grupo de soldados e de enfermeiras, e o outro é uma cena de júbilo de vários garotos e jovens ante um caminhão que levava o exército de Franco. Nenhum deles, contudo, foi publicado no Noticias Gráficas.

A classificação feita por Heras das outras imagens depende do lugar em que as cenas foram capturadas, sendo 49 tomadas nas ruas de Madri - a retaguarda - e 31 no front - a vanguarda. A temática da retaguarda gira em torno de três eixos: a representação de cenas de vida cotidiana protagonizadas por mulheres (14 fotografias), a devastação como

\footnotetext{
${ }^{7}$ Tradução livre do original: “¿Qué haces tú para evitar esto? Ayuda a Madrid.”
} 
consequência dos bombardeios da aviação inimiga (21) e a imagem dos milicianos (14). As mulheres foram classificadas de acordo com a função que desenvolveram durante o conflito, em três protótipos: a mulher dos costumes (responsável pela subsistência de sua família, mostra cenas de evacuação, da dor da perda e de mães e filhos), a sublime (além de responsável pela casa, é voluntária ou assalariada em trabalhos da retaguarda) e a antifascista (a militante ativa). A devastação também tem uma tríplice distinção: afetados diretamente (pessoas), destroços ocasionados em edifícios (construções) e tarefas de terraplanagem (mutirões organizados ou espontâneos). Já o terceiro eixo trata das imagens de milicianos que cobriam a defesa de Madri desde a retaguarda ou que desfrutavam de algumas horas de tranquilidade longe do front. Esses instantâneos foram divididos em "retaguarda civil", com 35 fotografias (dois primeiros eixos), e em "retaguarda militar", com 14 (terceiro eixo).

A vanguarda retrata ações no front de Madri. Das 31 fotografias, nove foram tomadas antes ou depois da batalha em distintas ocasiões: soldados recebendo instruções, deslocando-se para ocupar terrenos ou novas posições, milícias de vigilância revisando a documentação dos mobilizados e atendimentos de soldados feridos em combate. Onze imagens mostram ações diretas de guerra: cinco tomadas dos franquistas e seis dos defensores de Madri - como soldados disparando e avançando para chegar às trincheiras inimigas, canhões, peças de artilharia e legionários ocupando barricadas. Outros 10 instantâneos se centram no retrato de momentos de descanso dos soldados, tanto na hora de comida como em conversa com os companheiros, afeitando-se e, ainda, momentos de leitura, música ou aprendizagem. Fecha a coleção uma fotografia que mostra uma trincheira abandonada na Cidade Universitária, classificada por Heras como "outra".

A autora levantou que, das 83 imagens da Guerra Civil Espanhola, 48 foram publicadas no jornal Noticias Gráficas. Destas, seis foram veiculadas na ocasião da tomada e duas em datas diferentes. Curiosamente, nenhuma imagem da entrada dos franquistas em Madri foi publicada, bem como de nenhuma vítima fatal ou da busca de desaparecidos entre os 
escombros dos bombardeios. Também não se sabe quem são os autores das fotografias, exceto uma carimbada por Garrides. Sabe-se apenas que Oscar Kersenbaum distribuiu cinco imagens por meio da Agência Keynstone; a Associated Press Radio Photo, a Agência do Partido Comunista, a Internationalli News Service (através da King Features Sindicate) enviou uma imagem para o diário; a Photo TéléFrance, três; a Associated Press Photo via Paramount News of New York, quatro; e a Associated Press Photo enviou, diretamente, 26.

Não há como rastrear a origem de 41 instantâneos que não trazem nenhuma pista nas anotações em seus versos. Sobre estas anotações, Heras aponta que as fotografias, com a exceção de uma, traz textos manuscritos ou mecanicamente grafados sobre o próprio papel ou colados. Destas, 65 são acompanhadas de inscrições em espanhol, 16 em inglês e uma em francês.

Beatriz de las Heras apresenta o resultado de um trabalho realizado durante um período de pesquisa em 2007, realizado em Buenos Aires, financiado pela Fundação Carolina, instituição dependente do Ministério de Assuntos Exteriores da Espanha. Ela traz à tona um material inédito a respeito de um conflito muito importante na história do século XX, pois a Guerra Civil Espanhola é entendida como um laboratório, uma prévia do que seria a Segunda Grande Guerra. Além disso, mostra a dinâmica das agências de notícias e como os meios de comunicação se relacionavam, de forma intercontinental, no início dos anos novecentos. A autora traz, principalmente, um desafio para os próximos pesquisadores e para os leitores de sua obra: agir como historiadores e compor, ao menos, um pedaço do mosaico daquele conflito. Afinal, como afirma Heras (2009, p.15), "oferece-se ao leitor um material que pode servir como instrumento de análise para reconstruir o passado através da elaboração de um discurso visual que requer a montagem das fotografias como se fossem tesselas de um grande mosaico." 8

\footnotetext{
${ }^{8}$ Tradução livre do original: "se ofrece al lector un material que puede servir como instrumento de análisis para reconstruir el pasado a través de la elaboración de un discurso visual que requiere del ensamblaje de las fotografías como si fueran teselas de un gran mosaico".
} 